\title{
AOR
}

Selected Papers of \#AolR2020:

The 22nd Annual Conference of the Association of Internet Researchers Virtual Event / 13-16 Oct 2021

\section{'ETHICAL BIOMETRICS' AND THE FACE OF THE CHILD: THE SURVEILLANCE OF CHILDREN WITHIN FACIAL RECOGNITION INDUSTRY DISCOURSE}

\author{
Christopher O'Neill \\ Monash University \\ Gavin Smith \\ Australian National University \\ Mark Andrejevic \\ Monash University \\ Neil Selwyn \\ Monash University \\ Xin $\mathrm{Gu}$ \\ Monash University
}

In this paper we analyse data gathered through facial recognition tradeshow ethnographies and interviews with members of the biometrics industry, as we consider recent shifts in industry discourse towards promoting the 'ethical' use of biometric technology. As the biometrics industry increasingly moves towards a 'Video Surveillance as a Service' (VSaaS) model, the study of facial recognition infrastructures is becoming a crucial aspect of the interrogation of the Internet of Things.

We demonstrate that the facial recognition industry is acutely aware of critiques of facial recognition cameras and biometric technologies as enabling racialized and other forms of social harm (see Stark, 2019), and that members of the industry are keen to promote a more prosocial public image of the technology. Towards this end we find that biometric monitoring of children has gained a prominent place in the promotion of facial recognition technologies as a mode of 'careful' surveillance. We identify three key 'use cases' in which the face of the child takes on a prominent role as justifying and legitimating the use of facial recognition technologies - in the auditing of humanitarian food supply programs, in the detection of so-called 'staging' of family units at the US

Suggested Citation (APA): O'Neill, C, Smith, G, Andrejevic, M, Selwyn, N, Gu, X (2021, October). 'Ethical biometrics' and the face of the child: the surveillance of children within facial recognition industry discourse, Paper presented at AolR 2021: The 22nd Annual Conference of the Association of Internet Researchers. Virtual Event: AoIR. Retrieved from http://spir.aoir.org. 
border, and in the detection of underage gambling in Australia. We argue that the immanent 'ethical' framing of the child's face in this context serves to obscure the broader political ramifications of this extension of facial recognition and biometric surveillance tools more broadly.

These case studies are drawn from biometrics and security trade shows that we attended between July 2020 and July 2021, including the Biometrics Institute US congress (USA), the Biometrics Institute Global Congress (UK), the NEC Immersion+ showcase (Australia), the Identity Expo (Australia), the ISC West trade show (USA), the Security and Government Expo (Australia), and the $2^{\text {nd }}$ Annual Facial Recognition Summit (Singapore). We supplement this analysis with interviews with leading industry players.

There is a burgeoning literature on trade shows as a site of ethnographic practice, a site "where industries take shape and identities of professionals are created" (Nyquist, Leivestadt \& Tunestad, 2017: 1). As Hockenhul \& Cohn (2020) note, the speculations and pronouncements presented at such events are frequently dismissed as so much 'hot air' - as 'mere' speculation designed to inflate egos or company profiles. Yet, they argue that this is to miss a key aspect of the contemporary production of sociotechnical imaginaries (see Jasonoff \& Kim, 2015), the way that such speculation functions as "simultaneously vacuous and productive" (2020: 123). Tradeshow presentations serve as opportunities to outline imaginaries of a future where technology will provide answers to the seemingly intractable problems of today, while the grounded discussion of particular technologies and case studies demonstrates to audiences that these are not in fact 'idle' speculations - both presenter and audience understand themselves as seeing through the 'hype', and working to produce 'real' solutions (Hockenhull \& Cohn, 2020: 130). In this way the tradeshow emerges as a key site for understanding the way that a given industry 'understands itself' within a particular lineage of development and as projected into the future.

In our study we have found that a key means by which the industry seeks to 'ground' its claims is through the working through and negotiation of critiques of the industry, particularly in response to the argument that facial recognition cameras are racially biased. Biometrics companies are keen to reframe public attitudes of the technology away from being seen as a tool for policing, or as a cynegetic tool of tracing and capture (see Chamayou, 2012; Ginzburg, 2013), and instead as a means for the careful management of vulnerable subjects.

Perhaps the foremost figure in this effort is that of the child, and we argue that the face of the child has taken on a powerful rhetorical function, which aims at once to stand in metonymically for the control of deviant adult populations and at the same time to obscure the political consequence of the deployment of facial recognition technologies on a wide scale. As Lynne Wrennall (2010) has previously argued, surveillance technology companies have increasingly come to exploit the vulnerability of the child to promote the normalization of surveillance technologies which would otherwise be unpalatable or unacceptable when directed at adult populations. While the image politics around representing children have been predominately framed in ethical terms, around questions of a generalized duty of care, Dale Sampson has recently argued that 
to consider the face of the child in terms of an ethical relation is to obscure the "broader cultural politics of engagement with the child" (2020: 6), specifically the way that the 'face of the child' is figured as a political arrangement within a technics of recording and reproduction (see also Bueno, 2020; Edelman, 2004).

Beyond this, the focus on the face of the child as a problematic justifies further investment in the refinement of facial recognition algorithms. While facial recognition algorithms have attained ever greater levels of accuracy especially in the last several years, identifying the morphological changes of a growing child's face remains a difficult technological challenge, justifying the development of ever more sophisticated and complex technological fixes, which can in turn be deployed on the broader population. Because the child's face is always dissimulating itself, always becoming 'not-child', it is never fully captured (cf. Castañeda, 2002) - the biometrics industry is thus able to market ever more technological supplements, and require ever further refinements to surveillance infrastructures.

We draw attention to three key case studies in which the face of the child comes to serve as a justification for the careful deployment of facial recognition technologies - the use of facial recognition in the audit of aid supplies in the developing world, the control of alleged 'family staging' (by which a child is used to 'fake' a family unit for the purpose of beneficial treatment at the border), and in the monitoring of underage gambling in Australia. These three scenarios are both hugely divergent in their sociotechnical context, at the same time as the "face of the child", in its innocence and its recalcitrance, takes on a transversal quality which works to legitimate the function of the facial recognition apparatus across these different contexts. 


\section{REFERENCES}

Bueno, C. (2020) The Face Revisited Using Deleuze and Guattari to Explore the Politics of Algorithmic Face Recognition. Theory, Culture and Society 37(1): 73-91.

Castañeda, C. (2002) Figurations: Child, Bodies, Worlds. Duke University Press:

Durham (NC).

Chamayou, G. (2012) Manhunts: A philosophical history. Princeton University Press: Princeton.

Edelman, L. (2004) No Future: Queer Theory and the Death Drive. Duke University Press: Durham (NC).

Ginzburg, C. (2013) Clues, myths, and the historical method. Johns Hopkins University Press: Baltimore.

Hockenhull M \& M Cohn (2020) Hot air and corporate sociotechnical imaginaries:

Performing and translating digital futures in the Danish tech scene. In Hockenhull, M. Speculative Relations: Data And Digitalization Work In The Danish Public-private Tech Sector. PhD Thesis. IT University of Copenhagen 
Jasonoff, S \& Kim, S (eds), 2015 Dreamscapes of Modernity: Sociotechnical Imaginaries and the Fabrication of Power. Chicago University Press: Chicago.

Nyqvist A, H Leivestad and H Tunestad (2017) Individuals and industries: Large-scale professional gatherings as ethnographic fields. In Ethnographies of Conferences and Trade Fairs: Shaping Industries, Creating Professionals, edited by H Leivestad and A Nyqvist, 1-21. eBook. London: Palgrave Macmillan.

Stark, L (2019) Facial recognition is the plutonium of Al, XRDS: Crossroads, The ACM Magazine for Students, https://doi.org/10.1145/3313129.

Wrennall, L. (2010) Surveillance and Child Protection: De-mystifying the Trojan Horse. Surveillance and Society 7(3/4): 304-324. 